\title{
The Private Finance Initiative: An InNovative Procurement ToOl For Today's Public Administrators ${ }^{1}$
}

\section{By Seth Gabriel and Jordan Head}

Abstract: The Private Finance Initiative is an innovative public-private partnership first pioneered in the United Kingdom. The initiative's goal is to obtain higher quality public services at a lower cost to the public by engaging the private sector. The program relies on private financing and expertise, output-based contract specifications, performance-based payment mechanisms, and negotiated risk transfers to achieve this goal. This article discusses the initiative's successes and failures, using Her Majesty's Prison Service as a case study. The article finds that, while the program has limitations, the evidence of its successes suggests that American administrators should consider it as a procurement tool for public services in the United States.

"PFI is not rocket science - it is

just a different way of buying something."

-David Locke (Locke 2005)

\section{INTRODUCTION}

All procurement methods are not created equal. When a new method results in a nearly 90 percent ontime completion rate for contractors, in comparison with a 30 percent rate for traditional methods, public administrators have no choice but to take notice. The Private Finance Initiative (PFI), a form of public-private partnership pioneered in the United Kingdom (U.K.), has demonstrated this high completion rate (HMT 2003). The PFI uses private financing and expertise, output-based government specifications, performancebased payment mechanisms, and risk transfers with the goal of delivering quality public services at lower costs to citizens.

Seth Gabriel will graduate in May 2006 from The George Washington University with a master's degree in public administration and a concentration in government-business relations. He received a B.A. in political science in 2001 from Washington College of Chestertown. Maryland. Mr. Gabriel is currently a research assistant at The George Washington Center for the Study of Globalization, where his research focuses on public accountability.
This article will explain what makes the PFI different from other types of procurement and why administrators in the United States (U.S.) should consider using it. First, the article introduces the distinguishing characteristics of PFI projects. Next, the article evaluates the merits of the PFI by outlining the benefits and criticisms of the process, as well as discussing in which sectors the PFI is most and least successful, using the U.K.'s experience with prisons as an example. Finally, the article examines the potential relevance of the PFI for the U.S.

\section{Characteristics of the PFI}

The PFI is a specialized form of public-private partnership (PPP), the goal of which is to maximize private sector innovation while maintaining public accountability. Since most PFI projects occur over long

Jordan Head will graduate in May 2006 from The George Washington University with a master's degree in public policy and a concentration in urban and social policy. She holds a B.A. in economics from Southwestern University in Georgetown, Texas. Ms. Head is currently a research assistant at The George Washington Center for the Study of Globalization and is also an intern at the World Wildlife Fund. 
periods of time and include both construction and long-term maintenance components, several firms typically form a consortium to contract with the government authority. In principle, PFI projects share five basic characteristics: investment by the private sector, assignment of risks to the party best able to manage them, contracts focusing on outputs rather than inputs, capital infrastructure tied to long-term maintenance, and agreement at the outset on performance measures as the basis for scheduled payments. Another key concept in the theory of the $\mathrm{PFI}$ is value for money, which refers to obtaining the best performance for public money expended. The term also refers to the benefits achieved by transferring risks otherwise borne by the public sector to the private sector and by utilizing the private sector's expertise, efficiency, and innovation (Edwards et al. 2004).

\section{Private Sector Investment}

The most attractive aspect of the PFI is its reliance on outside investment, which reduces government expenditures on infrastructure projects and other public services. The PFI differs from other procurement methods because funding for project design and construction comes entirely from the private sector. The government makes no payment to the private contracting consortium until the facility is available for operations. Therefore, construction cost overuns and missed deadlines put the private consortium's capital at risk and provide a strong incentive for the consortium to fulfill its contractual obligations. The consortium must also ensure that a given facility remains continuously available in order to recover its capital investment over the life of the contract. This requirement provides an incentive to adequately maintain the facility. Penalties for failure to meet key performance indicators (KPIs), which are discussed in more detail below, are another incentive for private consortiums to maintain facilities. Although debate exists as to whether the penalties are large enough in practice to serve as a true deterrent, in principle this system protects PFI facilities from the cuts in maintenance budgets that governmentmanaged facilities sometimes face.

\section{Appropriate Allocation of Risks}

Risk allocation, determined through contract negotiations, is another crucial element of any PFI project. The purpose of sharing risk, similar to the purpose of requiring private investment, is to create incentives for the private sector to perform well and take responsibility for its service delivery. While the public sector must transfer sufficient financial risk to the private sector in order to secure value for money, the goal of this process is not to maximize the amount of risk transferred from the public to the private sector but to optimize the tisk transfer (House of Commons 2001).

Different projects involve different types of risks. For example, PFI road projects typically involve demand assessment, design, construction, and maintenance risks whereas PFI prison projects are more likely to involve availability, performance, and operating cost risks. In principle, the public sector retains many of these risks. In the design stage of projects, the public sector is responsible for specifying what services are needed based on the government's estimate of demand. The public sector is also responsible for ensuring that the standards established for the delivery of those services accurately reflect public needs and policy goals.

Although the costs to the public sector might be substantial if the government authority misreads demand or public needs, these risks provide incentive for the public sector to properly plan and manage resources. For example, if the government overestimates demand for prison cells, it must still pay the private sector for the delivery of services at the level specified in the contract, regardless of whether all cells are used. In some PFI schemes in the U.K., primatily real estate and accommodation projects, the public sector has managed to shift at least some of this demand assessment tisk to the private sector by negotiating an agreement whereby the government can transfer ownership of the unused space to the private sector which can then rent the space out to other clients. In traditional procurement methods, the public sector retains these types of demand and user risks and most PFI cases in the U.K. (and elsewhere) suggest that the government is best able to bear such risks. 


\section{Focus on Outputs}

More traditional forms of public service procurement force the public sector to focus too much on the development of non-mission aspects of the service, or the inputs. The use of the PFI changes that dynamic and shifts the government's focus to the outputs of a public services project. Instead of developing projects based on inputs (the paint color of the prison cells or the number of prison guards on duty at one time), the PFI framework forces the government to create longer-term contractual agreements in which the outputs received (room for 100 prisoners) and the outcomes achieved (accomplishing prison policy objectives) are the measures of success. In other words, the government must focus on the "what' not the 'how' of delivering public services" (Kee and Forrer 2004, 12). At the core of every PFI project is a concession contract in which the public sector specifies both the required outputs for the public service facility in question and the payment mechanism for the delivery of those outputs (HMT 2003).

Conventional procurement focuses on the purchase of tangible inputs - buildings, military equipment, and staffing - all things the government buys from the private sector to use in the process of providing public services. Under the conventional scheme, the public-private relationship is arms-length, with the private sector only responsible for providing the input items the government orders while the government retains all responsibility for converting those inputs into the outputs that it hopes will meet outcome goals. The PFI changes this relationship by requiring the government to set clear output requirements, called Key Performance Indicators (KPI), while the private sector uses its expertise and best practices to choose appropriate inputs. This approach takes advantage of the private sector's often superior abilities to provide innovative and efficient solutions.

\section{Capital Infrastructure Financing}

\section{Tied to Long-term Maintenance}

An industry representative involved in PFI prison projects remarked that " $[\mathrm{n}]$ icer prisons equal happier prisoners" (Cleal et al. 2005). This observation highlights the close link between well-designed infrastructure and positive long-term service outcomes. Public sector accounting and planning tend to be shortterm and, as a result, the design of public infrastructure projects might not include efficiency measures or accurate whole-life operational cost assessments. Under a 30-year PFI contract, however, private sector designers must take into account long-term operations and the economics of those operations before construction begins. Likewise, the government must precisely define its long-term service requirements before the service facility is designed. Thus, in principle, using the PFI to provide a public service is only appropriate if the public sector can define its needs as service outputs that can be contracted for the long term (HMT 2005).

The link between infrastructure design and longterm provision of service within that infrastructure also explains why private sector bidding costs on PFI contracts are considerably higher than under the conventional procurement system. However, limits on changes to contract requirements from the government mitigate these higher bidding costs. Contracting consortia forward the bids of their component companies on specific portions of PFI contracts, such as financing, construction, and soft services. The overall bid' must include all parts of the project in order to compete. Construction project managers must communicate with experts in the service field to find innovative and efficient designs. In the case of a new prison, design teams interview staff (guards, social workers, wardens) to discover what works and what does not work with respect to building design. Researching in advance ensures that the facility design is appropriate for prison operations and lowers the costs associated with those operations over the life of the contract. Furthermore, the private sector contractors are interested in building a high-quality facility because they are accountable for any future expenses due to poor facility design (HMT 2003).

\section{Key Performance Indicators}

Given the focus on outputs and the need for longterm maintenance, PFI projects also include KPIs. In each PFI contract, the private sector contractors and 
the government authority specify required outputs in key areas. The government authority sets KPIs to clearly and specifically state the level of output required.

Furthermore, if services are not provided in accordance with the KPIs, the government can reduce or delay payments to private sector service providers. In this way, KPIs provide the basis for the schedule of payments to private sector contractors. The government authority pays a monthly performancerelated service charge to the private sector based on both the capital expenditures made by the contractor and the continuous budgetary costs of running the facility and providing the necessary services. Generally, payment mechanisms are largely based on the billion ( $\$ 13.4$ billion) in 2002, representing a steady 10 to 15 percent annual increase in investment in public services over this period (HMT 2003). In March 2006, the Treasury announced that the PFI had delivered over 500 operational projects, including hundreds of health facilities, schools, transport, and other projects (HMT 2006). The Treasury also stated that the PFI continues to play an important role in public service provision in the U.K. albeit a role limited by strict value for money criteria. According to the report, over 700 projects worth over $£ 46$ billion have already been signed and the Treasury estimates that the PFI will account for approximately 10 to 15 percent of total investment in public services in the next five years with around 200

\section{FIGURE 1: DELIVERING ON TIME}

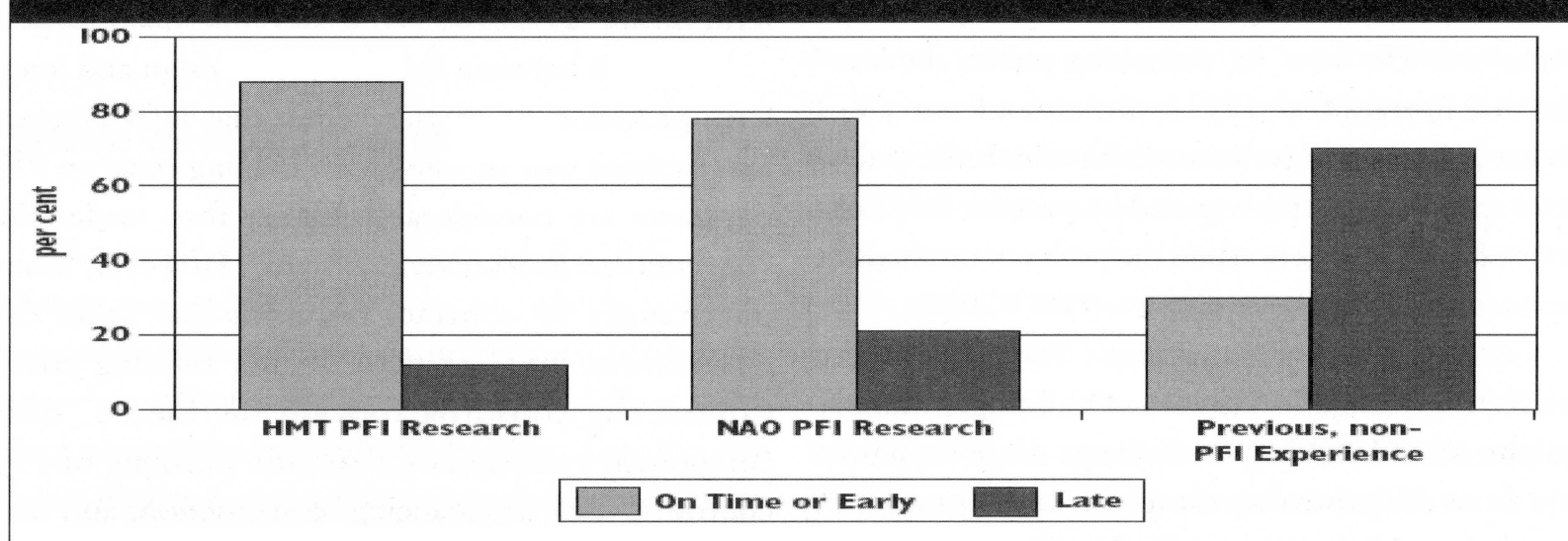

Source: HMT 2003. Meeting the Imvestment Challenge

availability of services provided (i.e. prisons must provide a specified number of places for prisoners; roads must be available to drivers throughout the day). If these availability requirements are not met, payments to the contractor decrease according to the number of "incomplete places." This shift of availability risk to the private sector partners generates many of the benefits of the PFI process.

\section{Beneftis and Prevalence of the PFI}

In a 2003 report, the U.K. Treasury estimated that the number and value of PFI projects had increased from nine projects with a value of $£ 667$ million $(\$ 1.2$ billion) in 1995 to 65 projects with a value of $£ 7.6$ projects worth $£ 26$ billion in projected capital value (HMT 2006).

Treasury data on PFI programs indicate that the PFI has resulted in higher rates of on-time and onbudget delivery. According to HMT's 2003 research, 89 percent of all PFI projects were delivered on time or early, as indicated in Figure 1 (HMT 2003). Furthermore, over 75 percent of PFI construction projects were delivered on time or early and only eight percent of PFI construction projects were over two months late (NAO 2003a). In contrast, only 30 percent of non-PFI major construction projects were delivered on time. In the case of prisons, which are discussed in more detail later, 80 percent of PFI prison projects were delivered on time (HMT 2003). 
HMT research also shows that all 61 PFI projects in its research sample were delivered within the public sector's budget (see Figure 2). Overall, 78 percent of PFI projects were within the public sector's budget, while only 27 percent of non-PFI projects were delivered within budget (NAO 2003a). Where budgeted costs had changed for PFI projects following contract signature, it was always the result of changing user requirements. In terms of construction performance, the private sector rather than the taxpayers assumed all construction cost overruns, representing a significant improvement over non-PFI experience (HMT 2003). This within-budget project completion record demonstrates a considerable improvement in the efficient use of public funds, as money previously used to fund cost overruns can instead be used to finance other public services.

\section{An Example of the PFI's Potential}

\section{Benefits: The U.K.'s Prison System}

One area in which the PFI appears to have been particularly successful is the U.K.'s prison system. Her Majesty's Prison Service (HM Prison Service), an executive agency of the Home Office, is responsible for the delivery of prison services in England and Wales. The overarching public policy objective of HM Prison Service is to protect the public by providing adequate facilities in a safe, decent, and healthy environment for prisoners committed by the courts (HM Prison Service 2005). In recent years, detention priorities have expanded to include rehabilitation programs that attempt to reduce crime by providing

\section{FIGURE 2: TRANSFERRING COST OVERRUN RISK}

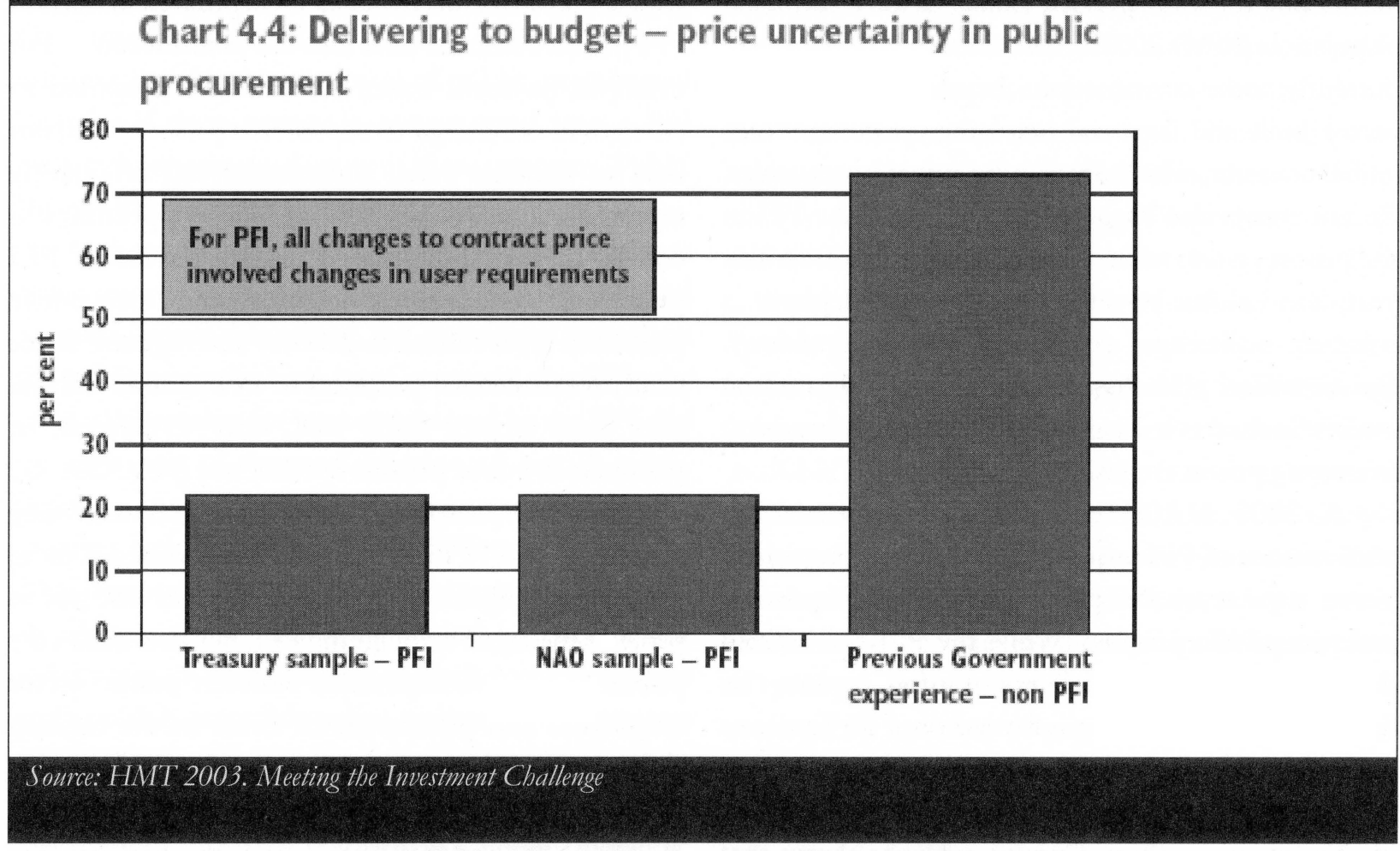

Although a definitive judgment about the performance of the PFI has yet to be made, government assessments suggest that PFI projects are largely meeting the expectations of the public sector. For example, managers surveyed by HMT for its 2006 study reported that 96 percent of PFI projects were performing satisfactorily or better (HMT 2006). constructive regimes that address the root causes of offending behavior. These programs aim to improve behavior among inmates — while in custody as well as after release - by improving education and work skills.

HM Prison Service currently addresses these overall policy objectives through four different 
organizational structures: public prisons, public prisons operating under a service level agreement, privately managed prisons, and PFI prisons. While public prisons still hold the bulk of the total prison population in the U.K., the PFI is fast becoming the preferred option for new prison construction and operation. FM Prison Service first turned to the private approach under the Conservative government of the 1990 s to meet growing demands on the public sector's capacity to handle prison services and, in particular, to develop more modern facilities to replace aging infrastructure - an acute problem for the HM Prison Service.

Due to the success of the PFI in the provision of prison services, private involvement in the field remains prevalent today. Four private sector contractors Group 4, Securicor, UKDS, and Premier - currently provide these services. There are seven operational PFI prisons in the U.K. (Altcourse, Ashfield, Dovegate, Forest Bank, Lowdham Grange, Parc, and Ryehill) accounting for seven percent $(5,000)$ of the total prison population (NAO 2003b). Two more PFI prisons are currently under construction. In addition, the public sector built and financed two other prisons, Wolds and Doncaster, which are run by private companies. Recent events also suggest that the use of the PFI in the prison system will continue to expand. Earlier this year, the Labour government announced plans to procure additional privately financed prisons. Furthermore, HM Prison Service has indicated an interest in market testing the PFI for service provision in existing prison estates.

A 2003 NAO report on the operational performance of PFI prisons offers a useful comparison between the seven PFI prisons, twelve public prisons, and two private prisons. While the PFI has offered definite benefits in the delivery of infrastructure, this report indicates that the performance of PFI prisons against contractual requirements has been mixed, pointing to success in some areas and the need for improvement in others. Current evidence shows that both the best and the worst performing prisons are PFI prisons. Of the seven best performing prisons, four are PFI prisons, two are privately managed, and one is a public prison. In the worst performing category, five out of the six prisons are public. Some of the early problems stem from changes in public sector requirements and in contractual and governance arrangements. These problems have been much more prevalent in the earliest PFI prisons and in the earliest stages of their operation (NAO 2003b). The NAO report does not, however, provide any indication of the sort of performance exhibited by public prisons immediately following startup. The accuracy of such a compatison is also questionable given significant differences in funding, design, age, and the operation of public prisons versus PFI prisons.

Some evidence from the use of the PFI in the prison system supports the theory that the bundled or single contractor approach of the PFI encourages innovation in the delivery of prison services by exploiting potential synergies that exist between designing, building, and operating a prison facility. Examples of innovations in PFI facilities include CCTV (closed-circuit television) video monitoting systems, modern radio accommodations, and design features such as control rooms at the center of a system of wings. Payment mechanisms incorporated in current PFI prison contracts have also led to innovations. For example, payment based on availability has led to changes in cell design to ensure that prisoners are not able to damage cells; a damaged cell effectively represents an unavailable cell and a lost opportunity to collect an availability-based unitary payment. ${ }^{2}$ PFI prisons also consistently perform better than public prisons in areas related to decency and regimes. While nearly 60 percent of prisoners in PFI prisons felt that they were treated fairly well, only 45 percent of prisoners in public prisons felt that way (NAO 2003b).

Lastly, the prospect of public prison services being turned over to PFI contractors has encouraged more efficient management of prison services not just in projects managed through the PFI, but also within the public sector. Competition between public sector employees and private sector firms in the bidding process lowers costs of capital and services over the long term, thus promoting cost efficiencies (Forrer et al. 2002). The insights gained from the performance of PFI prisons have led to the success of in-house government management teams in bidding against private sector teams for the operation of prisons. This public-private competition also promotes better accountability and performance in public prisons, improving management and conditions for prisoners (NAO 2003b). 


\section{Criticisms of THE PFI}

Although this evidence suggests that the PFI might offer significant benefits, the initiative continues to face criticism. The program stirred strong political opposition even at its origin under the Conservative government, as opponents perceived it as a back-door way of furthering the privatization policies of Margaret Thatcher. The PFI remains politically controversial despite the fact that Prime Minister Tony Blair's government has continued to use the PFI since its election to power in 1997. In particular, the U.K.'s public employee labor unions have objected to the initiative over fears that government agencies and private firms would view it as a means to cut labor costs by eliminating government jobs. However, longstanding laws, such as the Transfer of Undertakings (Protection of Employment) Regulations of 1981 (TUPE), and recent legislation, such as the Local Government Act of 2003, through which employees are guaranteed legal protection of public employment benefits if their agency is restructured into a PFI project, have mitigated some of these concerns (Public Private Partnerships Programme 2005).

Other criticisms and concerns address transparency and the apparent lack of limitations placed on consortium companies, the limitations placed on the public sector by long-term contracts, the difficulty of assessing value for money achieved by the PFI and the high cost of the marketization of certain public services. As for the issue of transparency and the seeming lack of limitations on PFI contractors, the 2006 Treasury report outlines government measures to address these concerns, including the regular publication of several types of disclosure documents and a publicly accessible online database of PFI projects (HMT 2006). While many private contractors might be unaccustomed to this level of public scrutiny, members of the U.K. Parliament's Public Accounts Committee have argued forcefully that "if you are a contractor taking money from taxpayers for providing services, you have to accept that that entails on your part a higher degree of disclosure and a higher degree of transparency than would be the case if you were operating purely in the private sector" (BBC Radio 4 2004).
A second major concern is whether long-term PFI contracts limit public sector flexibility to respond to changing public needs. As Hall states: "Whilst the initial evidence on value for money from the use of private finance provides some grounds for optimism, doubts exists over... whether long-term contractual commitments will reduce the flexibility with which the public sector can respond to changing circumstances" (Hall 1998, 135). Thus, the true impact of PFI contracts on the ability of the public sector to meet changing needs is yet unknown. This inability to estimate the future circumstances of public service might lead to limiting the use of the PFI to those services less likely to experience dramatic changes, such as prisons and office facilities.

In addition, the value of a PFI project in comparison to a publicly financed project can be difficult to measure. Attempts have been made to draw value for money comparisons between the PFI and the Public Sector Comparator, a theoretical construct that represents the costs and risks to the public sector if the proposed project were completely government financed and managed. However, many experts in the procurement field view these value for money comparisons between PFI projects and the Public Sector Comparator as nothing more than political exercises (Heald 2003). Heald argues that the "public sector comparator... is implicitly excluded; it is used as the benchmark for appraising the PFI, though it is made explicit that there is no Exchequer ${ }^{3}$ finance available" (Heald 2003, 345-346). That is to say, if the government decides that the PFI is the only method that it will use for procuring public projects, or if the economic realities dictate this course, the process of determining the value for money of a PFI project has no policy value. In these cases, as Heald argues, the outcome of a review of project funding options will result in one of three options: (1) a publicly financed fallback position (or at the very least the public sector can provide funding to mitigate the situation), (2) the PFI, or (3) the status quo (Heald 2003). The PFI process will win the value for money review by default because the fallback position and the status quo are both politically intolerable options.

Furthermore, the monetary costs of the marketization of certain public services are so high that the PFI process has had difficulty achieving value 
for money in those sectors. The National Health Service (NHS) has experienced this problem for much of the history of the PHI. As one observer notes, "private-sector firms that had tried to set up PFI hospital projects found them difficult to otganise and expensive to bid for. A major hurdle was the raising of finance as the funding institutions felt that the risks involved in financing such projects wete too great" (Kerr 1998, 2285). As in the U.S., medical care in the U.K. is a riskier business than prisons or roads even within a system of universal public health care. This level of risk can make the costs of financing and bidding on PFI hospital contracts especially high. increasing budgets and lowering the value for money of the entire project.

These problems can also lead to the exit of private sector contractors from the bidding field, as in the case of an $t^{80}$ million hospital project in Oxford, where all four bidders backed out, leaving the two NHS Trusts commissioning the scheme to start the PFI process all over again (Kerr 1998). The removal of some or all contractors from the bidding process can result in contracts that are poor investments for the public sector or in complete project failure. Opponents of the PFI point to the eatly hospital cases as examples in which the public sector can provide public services at a lower cost than the private sector.

Despite the positive data on the PFI's benefits, practitioners must consider caveats about the PFI as weil. As Edwards and her coauthors point out in their discussion of information technology projects, "numerous IT PFI projects have failed. Several PFI/ PPP projects have had to be bailed out, some have been scrapped and others have been the subject of widespread criticism" (Edwards et al. 2004, 7). Not every PFI project is a success and some are outright failures. PFI contracts can involve high bidding costs, limited flexibility and politics over projects. Public administrators must consider these limitations when investigating what relevance the PFI might have as a procurement tool in the U.S.

\section{Partnerships in the United}

\section{STATES}

Although the PHI per se has not been tried in the U.S., similar public-private partnerships have met with success here, suggesting that the PFI experience in Britain might offer valuable lessons for U.S. procurement officials. Several agencies within the federal government as well as many state and local governments have entered into partnership agreements.

The U.S. Army is currently working with the Actus lend Lease Corporation in a special joint venture to build over 83,000 new housing units for American military personnel. This partnership matches a $\$ 701$ million invesment by the U.S. Army with a $\$$ ) billion private investment from Actus Lend Lease under a 50-year management agreement to provide quality housing for American military personnel (Armbruster and Menhinnitt 2005).

At the state government level, many transportation departments are examining how best to create partnerships beyond simply privatizing roads. States including Texas (the Trans-Texas Corridor), Florida, and Virginia have entered into public-private partnerships of varying styles to provide improved transportation services to their residents. In Virginia, arguably the leader in public-private partnership usage among the American states, the Public Private Transportation Act (PPTA) of 1995 allowed the Virginia Department of Transportation to enter into agreements with private contractors for the construction, maintenance and operation of transportation facilities (Homer 2005). Since the passage of the PPTA, the Virginia Department of Transportation has partnered with private sector contractors in the Route 288 and Pocahontas Parkway projects with more projects underway, including the Capital Beltway (Interstate 495) high occupancy toll lanes project (Homer 2005).

County and municipal governments have also looked to public-private partnerships for the design, finance, construction and operations needs of new projects, primarily in the transportation sector. The Hiawatha Light Rail project in Minneapolis is a prime example of an American-style partnership involving the federal government, the State of Minnesota, the City of Minneapolis, Hennepin County Regional Rail Authority, the Metropolitan Airport Commission, the Mall of America, and local and international construction companies (Fuhrmann 2005). A betterknown municipal-level partnership is the Chicago 
Skyway Btidge agreement between the City of Chicago and the Skyway Concession Company, LLC. This contractual agreement shifts maintenance risk to the private contractor in exchange for a 99 -year concession contract, in which the private company buys the rights to toll revenue in exchange for the risk of operating the public service.

Many of these PFI-like projects are viewed simply as a way of gaining non-tax revenue and divesting maintenance obligations or as nothing more than privatization or toll concession agreements'. However, these projects show that the PFI benefits experienced in the U.K. can also be realized here, if American public administrators learn to view and operate these publicprivate partnerships as the powerful procurement tools they are.

\section{ConCLusion}

This article has demonstrated that, although the PFI might not be a flawless procurement tool appropriate for every type of public service, it can be a compelling alternative to both conventional contracting methods and to direct public funding and service provision. As Professor Jane Broadbent and her colleagues have cautioned, any meaningful evaluation will take several years to complete because of the length and complexity of PFI contracts. With contracts running over 60 years, where the costs shift over time, any hope of conducting a comprehensive evaluation at this point is impossible (Broadbent 2003). Yet the data to date are promising and the example of HM Prison Service, in particular, remains an intriguing illustration of the PFI's potential. The American experience with public-private partnerships suggests that the PFI is an option which public administrators could realistically adopt here and that the benefits of PFI projects might be transferable to and beneficial for the provision of public services in the U.S.

\section{Notes}

${ }^{1}$ The authors wish to thank Sarah Fox and Tanya Qadir at The George Washington University in Washington, D.C., for their collaboration in researching and writing the unpublished paper that was the genesis of the present article, "Market-Based Provision of Public Service: Prison Research" (July 23, 2005).

2 PFI contracts promise "unitary payments" to prison contractors based on the number of available spaces for prisoners. If, for example, the specified number of cells or clean uniforms, meals per day, counseling services, books, etc., for one "space" are not provided, payments to the consortium are deducted by a predetermined "per space" amount.

${ }^{3}$ The U.K. Exchequer is the government funding agency, similar to the Treasury in the U.S.

${ }^{4}$ For example, the Skyway Concession Company paid $\$ 1.8$ billion to the City of Chicago for the rights to toll revenue as part of their public-private partnership agreement (Skyway Concession Company, LLC 2005).

\section{References}

Armbruster, W. A., and M. Menhinnitt. 2005. Military accommodation case study: Military Housing Privatization Initiative. Presentation at The $2^{\text {nd }}$ Annual PPP/P3 Global Summit, December 6-7, in Washington, D.C., U.S.

British Broadcasting Corporation, Radio 4 (BBC Radio 4). 2004. Current Affairs Group - "File On 4." Producer: Ian Muir-Cochrane, Report: Gerry Northam, Editor: David Ross. Transmission: 6 July.

Broadbent, J., J. Gill, and R. Laughlin. 2003. Evaluating the Private Finance Initiative in the National Health Service in the U.K. Accounting, Auditing and Accountability Journal 16:422-445.

Cleal, P., S-J. Eglen, P. Newman, and C. Walsh. 2005. PFI ptisons in the United Kingdom. Presentation to The George Washington University, July 1, in London, U.K. 
Edwards, P., J. Shaoul, A. Stafford, and L. Arblaster. 2004. Evaluating the operation of PFI in roads and hospitals, Research Report No. 84. Certified Accountants Education Trust. London: The Association of Chartered Certified Accountants.

Forter, J., J. E. Kee, and Z. Zhang. 2002. Private Finance Initiative: A better public-private partnership? The Public Manager 31:43-47.

Fuhrmann, M. W. 2005. Case study: Hiawatha Light Rail. Presentation at The $2^{\text {nd }}$ Annual PPP/P3 Global Summit, December 6-7, in Washington, D.C., U.S.

Hall, J. 1998. Private opportunity, public benefit? Fiscal Studies. Accoutnting and Tax Periodicals 19:121-140.

Heald, D. 2003. Value for money tests and accounting treatment in PFI schemes. Accounting, Auditing, and Accountability Journal 16:342-71.

Her Majesty's Prison Service. Statement of purpose - About the service. London: HMT. http:// www.hmprisonservice.gov.uk/abouttheservice/ statementofpurpose/ (accessed September 27, 2005).

Her Majesty's Treasury (HMT), 2003. PFI: Meeting the investment challenge. London: HMT.

2005. The role of HM Treasury in PFI. London: HMT.

2006. PFI: Strengtbening long-term partnerships. London: HMT.

Homer, P. 2005. Public Private Transportation Act in Virginia. Presentation at the Public Private Partnership Forum, December 16-17, in Glen Allen, VA, U.S.

House of Commons. 2001. The Private Finance Initiative (PFI) - Research Paper 01/117. London: House of Commons Library.

Kee, J. E., and J. Forrer. 2004. Private Finance Initiative - The theory behind the practice. Presented at the 14th Annual Conference of the Association for Budgeting and Financial Management, October 10. 12, 2002, in Kansas City, Missouri.
Kert, D. 1998. The Private Finance Initiative and the changing governance of the built environment. Urban Studies 35:2277-2301.

Locke, D. 2005. Public Private Partnerships Programme: PFI in the United Kingdom. Presentation at The George Washington University, June 29, in London, U.K.

National Audit Office (NAO). 2003a. Construction performance 2002. HC 371, Session February 20022003. London: NAO.

-2003b. The operational performance of PFI prisons. HC 700 Session 2002-2003: 18 June 2003. London: NAO.

Public Private Partnerships Programme. 2005. Local government employment and equality issues. London:4ps.

Skyway Concession Company, LLC. 2005. About The Chicago Skyway. http://www.chicagoskyway.org/ about/ (April 13, 2006). 